\title{
HERD LEVEL RISK FACTORS FOR ELEVATED TOTAL BACTERIAL COUNT IN BULK TANK MILK OF DAIRY HERDS
}

\author{
A. M. Elmoslemany ${ }^{a}$ and G. P. Keefe ${ }^{b}$
}

a Department of Hygiene and Preventive Medicine, Faculty of Veterinary Medicine, Kafrelsheikh University, Egypt, P.O. Box 33516

b Department of Health Management, University of Prince Edward Island, Charlottetown, PEI, C1A 4P3

\begin{abstract}
The aim of this study was to determine the risk factors associated with high total bacterial count of bulk tank milk. Bulk tank milk samples were collected from all Prince Edward Island dairy herds (n=235) from March 2005 to March 2007. Biweekly total bacterial count was conducted using a Petrifilm culture system. Data for on-farm risk factors were collected via a mail-out survey which consisted of 4 main sections: 1) general farm demographics and management, 2) cow cleanliness and hygiene, 3) milking procedures and mastitis control, and 4) equipment maintenance and cleaning.

The total bacterial count was positively associated with the amount of soiling on the teats prior to udder preparation, manual cleaning of the bulk tank, and the use of a certain type of detergent. Additionally, various methods of premilking udder preparation were important, with predip followed by drying being superior to other methods in reducing bacterial count. Season was a strong predictor, with the lowest count tending to occur in winter. The results of this study highlight the importance of total bacterial count as indicator of on-farm management practices, which influence bacteriological quality of milk.
\end{abstract}

Key words: bulk tank milk, total bacterial count, risk factors 


\section{INTRODUCTION}

Periodic examination of bulk tank milk (BTM) is useful for monitoring and evaluating raw milk quality produced on the dairy farm. High bacterial counts in raw milk can affect the quality of pasteurized milk and milk products resulting in lowered shelf life and reduced consumer acceptance of milk and milk products (Barbano et al., 2006; Jayarao et al., 2006; Keefe and Elmoslemany, 2007). Therefore, many jurisdictions include limits on the total number of bacteria in raw milk to ensure quality and safety of the final product.

The total bacterial count (TBC) is a recognized alternative and equivalent to the standard plate count (SPC) and is the most common method for evaluation of bacterial quality of raw milk (Wehr and Frank, 2004). The TBC estimates the total number of bacteria present in raw milk at the time of pick up from the farm. It provides an overall measure of hygienic quality of milk.

At the farm level, microbial contamination of bulk tank milk (BTM) occurs via 3 main sources: bacterial contamination from the external surface of the udder and teats, from the surface of the milking equipment, and from mastitis organisms from within the udder (Murphy and Boor, 2000). Although it is well recognized that good quality raw milk is essential for producing quality milk and milk products, there is limited information available on the influence of various management factors on bulk tank bacterial counts. Therefore the objective of this study was to assess the relationships between herd management practices and bacterial levels that characterize the hygienic quality of raw milk.

\section{MATERIALS AND METHODS}

\subsection{Milk sampling:}

Bulk tank raw milk was collected from all Prince Edward Island dairy herds $(n=235)$ every other week by licensed milk haulers over a two-year period (March 2005 to March 2007). Samples were collected in 
$30 \mathrm{~mL}$ sterile screw cap tubes (Starplex Scientific Inc., Etobicoke, Ont.) and held on ice until arrival at the laboratory. All microbiological analyses were performed within 36 hour of pick-up at the farm.

\section{2. On-farm data collection:}

For collecting data on risk factors, a questionnaire was designed with closed questions only. The questionnaire was comprised of 4 main sections (general farm demographics and management, cow cleanliness and hygiene, milking procedures and mastitis control, and equipment maintenance and cleaning) with 6 pages and 50 variables, and was pretested on 3 farm owners for clarity and ease of administration. The questionnaires were changed and improved where necessary. The final version of the questionnaire was sent to all dairy farms in PEI in October 2005, with telephone follow-up for all non-responders. Copies of the questionnaire are available from the senior author upon request.

\subsection{Bacteriological analysis of BTM:}

Bulk tank milk samples were examined for TBC using Petrifilm culture system (3M Canada, London Ontario). The TBC was conducted according to Standard Methods for the Examination of Dairy Products (SMEDP) procedures (Wehr and Frank, 2004) using 1/100 dilution of milk. Plates for enumeration of TBC were incubated at $32^{\circ} \mathrm{C}$ for $48 \mathrm{~h}$ after which bacterial colonies are counted and the number expressed as colony-forming unit per milliliter $(\mathrm{cfu} / \mathrm{ml})$.

\subsection{Statistical analysis}

Data from questionnaires were coded and entered twice with dataentry software (EpiData Entry; Lauritsen and Bruus, 2006), and both entries were compared, to check for errors. A new variable representing premilking udder preparation was created from combinations of the variables: dry wipe, teat wash, pre-dip, and udder drying.

Association between management practices and TBC in bulk tank milk was examined using a linear mixed model with herd random effects and autoregressive correlation structure for the repeated measures on 
herds (PROC MIXED; SAS software version 9.1; SAS Institute, Inc., Cary, NC). To approximate the normal distribution, a natural logarithmic transformation of the TBC was used.

Potential risk factors for TBC were initially screened using unconditional associations $(P<0.15)$. Subsequently, multivariable analysis was conducted and predictors with $P<0.05$ were retained in the final model. Model building procedures were followed according to Dohoo et al. (2003).

\section{RESULTS}

Of 235 producers, 153 completed the mail out survey giving a response rate of $65 \%$.

\subsection{Unconditional associations:}

The univariable associations $(P<0.15)$ between management factors and TBC are reported in Table 1 . The TBC was positively associated with the following premilking udder preparation procedures: dry wiping of all teats, not using pre-dip, and using the same towel for udder drying or not drying the udder at all. On the other hand, udder hair clipping, and using detergents, acids, and sanitizers at higher frequency (twice vs. once or less/day) were protective.

\subsection{Multivariable model for TBC:}

Table 2 shows the risk factors for elevated TBC. The mean log TBC was positively associated with the presence of $>10 \%$ of cows with dirty teats prior to udder preparation and with using a dry wipe or water to wash the teats versus the use of pre-dip. Using a commercial disinfectant towel alone (without subsequent drying) was also associated with elevated TBC. Additionally, manual cleaning of the bulk tank and use of a certain type of detergent were also associated with high TBC. Season was strongly associated with $\mathrm{TBC}$, where the association was positive during summer and negative during winter. The distribution of the variances in the final TBC model indicates that most of the variation was attributed to within-herd variances and the intra-class correlation coefficient was 0.09 which indicates weak correlation between 2 observations from the same herd. 
Herd Level Risk Factors For Elevated Total ...

Table (1): Variables associated $(P<0.15)$ with total bacterial count in bulk tank milk of 153 dairy herds in Prince Edward Island.

\begin{tabular}{|c|c|c|c|}
\hline \multirow{2}{*}{ Variable } & \multirow{2}{*}{ Percent } & \multicolumn{2}{|c|}{ TBC $^{\mathbf{a}}$} \\
\hline & & Estimate & $\bar{P}$ \\
\hline - Stall base & & & $0.10^{\mathrm{b}}$ \\
\hline Concrete & 33 & - & - \\
\hline Mattress & 27 & -0.23 & 0.03 \\
\hline Rubber & 30 & -0.09 & 0.37 \\
\hline Clay & 10 & -0.25 & 0.08 \\
\hline \multicolumn{4}{|l|}{ - Frequency of bedding change } \\
\hline Once or more/day & 82 & & \\
\hline One or Less every 2 days & 14 & 0.24 & 0.05 \\
\hline Less than two/week ${ }^{c}$ & 4 & & \\
\hline \multicolumn{4}{|l|}{ - Udder hair clipping } \\
\hline Yes vs. no & 70 & -0.21 & 0.02 \\
\hline $\begin{array}{l}\text { - Cows with manure on teats prior to udder preparation in } \\
\text { winter }\end{array}$ & & & $0.10^{\mathrm{b}}$ \\
\hline$<5 \%$ & 50 & - & - \\
\hline $5-10 \%$ & 31 & 0.10 & 0.28 \\
\hline$>10 \%$ & 19 & 0.23 & 0.03 \\
\hline \multicolumn{4}{|l|}{ - Pre-milking udder preparation } \\
\hline Dry wipe & & & $0.07^{\circ}$ \\
\hline All teats & 35 & - & - \\
\hline Dirty teats only & 8 & -0.32 & 0.06 \\
\hline None & 57 & -0.17 & 0.06 \\
\hline - Teat wash & & & $0.04^{\mathrm{b}}$ \\
\hline All teats & 37 & - & - \\
\hline Dirty teats only & 8 & -0.01 & 0.93 \\
\hline None & 55 & -0.22 & 0.01 \\
\hline - Pre-dip & & & $<0.01^{\mathrm{b}}$ \\
\hline Teat dipper & 43 & - & - \\
\hline Teat sprayer $^{\mathrm{c}}$ & 4 & & \\
\hline Commercial disinfectant towel & 9 & 0.28 & 0.07 \\
\hline None & 44 & 0.36 & $<0.01$ \\
\hline - Udder drying & & & $<0.01^{\mathrm{b}}$ \\
\hline Single paper towel & 67 & - & - \\
\hline Single use cloth & 14 & 0.05 & 0.70 \\
\hline Multi-use towel & 10 & 0.37 & $<0.01$ \\
\hline Not used & 9 & 0.55 & $<0.01$ \\
\hline \multicolumn{4}{|l|}{ - Bulk tank cleaning } \\
\hline Manual vs. automated & 13 & 0.36 & $<0.01$ \\
\hline \multicolumn{4}{|l|}{ - Frequency of pipeline detergent use } \\
\hline Twice or more/day vs. once/day & 95 & -0.34 & 0.08 \\
\hline \multicolumn{4}{|l|}{ - Frequency of pipeline acid use } \\
\hline Twice or more/day & 92 & - & - \\
\hline Once/day & 5 & 0.56 & $<0.01$ \\
\hline Other $^{\mathrm{c}}$ & 3 & & \\
\hline \multicolumn{4}{|l|}{ - Frequency of bulk tank detergent use } \\
\hline Each pickup vs. every second pickup & 91 & -0.31 & 0.03 \\
\hline
\end{tabular}

\footnotetext{
${ }^{\mathrm{a}} \mathrm{TBC}=$ total bacterial count.

${ }^{\mathrm{b}}$ The overall P-value for variables with multiple categories.

${ }^{\mathrm{c}}$ Categories with less than $5 \%$ of observations were not included in the analyses.
} 
A. M. Elmoslemany \& G. P. Keefe

Table (2): Linear mixed model of risk factors associated with the mean natural log total bacterial count in raw milk based on 153 dairy herds in Prince Edward Island.

\begin{tabular}{|c|c|c|c|}
\hline Variables & Estimate & S.E. & $\boldsymbol{P}$ \\
\hline \multicolumn{4}{|l|}{ - Fixed part of the model } \\
\hline Intercept & 8.63 & 0.15 & $<0.01$ \\
\hline - Percent of manure on the teat prior to udder prep. in winter & & & $0.04^{\mathrm{a}}$ \\
\hline$<5 \%$ & - & - & - \\
\hline $5-10 \%$ & 0.06 & 0.09 & 0.45 \\
\hline$>10 \%$ & 0.26 & 0.10 & 0.01 \\
\hline - Pre-milking udder preparation & & & $<0.01^{\mathrm{a}}$ \\
\hline Pre-dip and drying & - & - & - \\
\hline Commercial towel and drying & 0.07 & 0.18 & 0.69 \\
\hline Wash and dry with single towel/ no dry & 0.32 & 0.09 & $<0.01$ \\
\hline Wash and dry with multiple towel & 0.51 & 0.19 & $<0.01$ \\
\hline Dry wipe with single or multitowel & 0.54 & 0.14 & $<0.01$ \\
\hline Commercial towel, no drying & 0.79 & 0.22 & $<0.01$ \\
\hline \multicolumn{4}{|l|}{ - Bulk tank cleaning } \\
\hline Manual vs. automated & 0.24 & 0.11 & 0.03 \\
\hline \multicolumn{4}{|l|}{ - Pipeline detergent } \\
\hline Detergent 2 vs. others & 0.40 & 0.11 & $<0.01$ \\
\hline \multicolumn{4}{|l|}{ - Study year } \\
\hline Year two vs. year one & 0.18 & 0.06 & $<0.01$ \\
\hline - Season & & & $<0.01^{\mathrm{a}}$ \\
\hline Spring & - & - & - \\
\hline Summer & 0.33 & 0.06 & $<0.01$ \\
\hline Fall & -0.01 & 0.07 & 0.89 \\
\hline Winter & -0.12 & 0.07 & 0.08 \\
\hline - Season*year & & & $<0.01^{\mathrm{a}}$ \\
\hline Summer*year2 & 0.06 & 0.09 & 0.53 \\
\hline Fall*year2 & 0.51 & 0.09 & $<0.01$ \\
\hline Winter*year2 & -0.42 & 0.09 & $<0.01$ \\
\hline \multicolumn{4}{|l|}{ - Random part of the model } \\
\hline Intercept & 0.17 & 0.02 & $<0.01$ \\
\hline Residual & 1.74 & 0.03 & $<0.01$ \\
\hline
\end{tabular}

a The overall P-value for variables with multiple categories. 


\section{DISCUSSION}

The amount of dirt on the teats prior to pre-milking udder preparation was positively associated with TBC. Dirty udders and teats are considered important sources of environmental bacteria in milk (Pankey, 1989). Additionally, Vissers et al. (2007) indicated that the concentration of microorganisms transmitted to milk via dirty teats depended on the amount of dirt and the concentration of microorganisms in this dirt. Subsequently reducing the amount of dirt on the teats will reduce the risk of microbial contamination of milk.

Previous studies have also reported a positive association between the degree of udder contamination and the level of mastitis as measured by individual cow linear score (Schreiner and Ruegg, 2003; Reneau et al., 2005; Ellis et al, 2007). Additionally, Schreiner and Ruegg (2003) reported that dirty cows were 1.5 times more likely to be infected with a major mastitis pathogen than clean cows. Previous research by our group also found a positive association between udder hygiene score and bacterial counts in BTM (Elmoslemany et al., 2009 a and $b$ ).

Effective premilking udder hygiene is important for the production of high quality milk and the control of mastitis. The objective of premilking udder preparation is to milk clean and dry teats (Galton et al., 1986; Pankey, 1989). Premilking teat disinfection has been associated with reduction in SPC and coliform count (Galton et al., 1986; Pankey, 1989), SPC and preliminary incubation count (Jayarao et al., 2004; Elmoslemany et al., 2009b), and total bacteria and anaerobic spore counts (Rasmussen et al., 1991; Magnusson et al., 2006). On the other hand, Gibson et al. (2008) reported no association between premilking teat-cleaning regime and total bacterial, Enterobacteriaceae, and Escherichia coli levels in milk. 
In this study pre-dipping followed by drying the teats with singleuse towel was associated with the lowest bacterial counts compared to other methods of teat preparation. Pre-dipping the teats with approved disinfectant is considered the most effective way of teat disinfection and drying of the teats before milking is considered the most important step in a teat cleaning regime (Ruegg, 2004).

Using water to wash the teats without drying was associated with elevated TAC. Water laden with bacteria on the udder and teat surfaces can enter the teat cup liners and increase bacterial contamination of milk (Galton et al., 1982). The efficiency of a commercial disinfectant towel in reducing TBC was related to the method of use. When used alone, it was associated with the highest bacterial counts. However, when followed by drying, their effect was not different from pre-dipping and drying. These results indicate that the use of a medicated towel alone does not adequately kill and remove bacteria from the teats. Additionally, these results indicate that manual drying of the teats is an important step for reducing bacterial burden of the teats. The effect of manual drying may be related to physical action on the teat surface and scrubbing of the teat ends (Rasmussen et al., 1991).

The results related to premilking udder preparation highlight the importance of chemical sanitization and udder drying in premilking teat cleaning effectiveness, as has been reported by others (Pankey, 1989; Magnusson et al., 2006).

Manual cleaning of the bulk tank was also associated with an increased risk of elevated TBC. Manual cleaning of the bulk tank was associated with a lower frequency of detergent and acid use. In another 
study, manual cleaning was also associated with lower temperature of the cleaning solution (Elmoslemany et al., 2009b). The use of a certain type of detergent was also a risk compared to other types. This detergent was a powdered chlorinated detergent available in bulk. The reason for reduced efficiency may be related to improper storage of the product which allows the loss of chlorine during storage.

The TBC tended to be high in summer and low during winter. High TBC during summer months has been reported previously (Soler and Ponsell, 1995; Van Schaik et al., 2002). Higher counts during summer may be related to warmer ambient temperature allowing bacteria to grow faster.

\section{CONCLUSION}

This study highlights the importance of using TBC as indicator of on-farm hygienic conditions during milk production. The TBC was mainly associated with the proportion of cows soiled with manure, method of premilking udder preparation, and manual cleaning of the bulk tank. The within herd autocorrelation was weak suggesting that herd evaluation cannot rely on a single observation.

\section{REFERENCES}

- Barbano, D. M., Y. Ma, and M. V. Santos. (2006): Influence of raw milk quality on fluid milk shelf life. J. Dairy Sci. 89(E Suppl.):E15E19.

- Dohoo,I.R., Martin, W., Stryhn, H., (2003): Veterinary Epidemiologic Research. AVC Inc., University of Prince Edward Island, Charlottetown, Prince Edward Island, Canada. 
- Ellis, K.A., Innocent, G.T., Mihm, M., Cripps, P., McLean, W.G., Howard, C.V., Grove-White, D., (2007): Dairy cow cleanliness and milk quality on organic and conventional farms in the UK. J. Dairy Res. 74, 302-310.

- Elmoslemany, A.M., Keefe, G.P., Dohoo, I.R., Jayarao, B.M., (2009a): Risk factors for bacteriological quality of bulk tank milk in Prince Edward Island dairy herds. Part 1: Overall risk factors. J. Dairy Sci. In press.

- Elmoslemany,A.M., Keefe, G.P., Dohoo, I.R., Jayarao, B.M., (2009): Risk factors for bacteriological quality of bulk tank milk in Prince Edward Island dairy herds. Part 2: Bacteria count specific risk factors. J. Dairy Sci. In press.

- Galton, D.M., Adkinson, R.W., Thomas, C.V., Smith, T.W., (1982): Effects of premilking udder preparation on environmental bacterial contamination of milk. J. Dairy Sci. 65, 1540-1543.

- Galton, D.M., Petersson, L.G., Merrill, W.G., (1986): Effects of premilking udder preparation practices on bacterial counts in milk and on teats. J. Dairy Sci. 69, 260-266.

- Gibson, H., Sinclair, L.A., Brizuela, C.M., Worton, H.L., Protheroe, R.G., (2008): Effectiveness of selected premilking teat-cleaning regimes in reducing teat microbial load on commercial dairy farms. Lett. Appl. Microbiol. 46, 295-300.

- Jayarao, B.M., Pillai, S.R., Sawant, A.A., Wolfgang, D.R., Hegde, N.V., (2004): Guidelines for monitoring bulk tank milk somatic cell and bacterial counts. J. Dairy Sci. 87, 3561-3573. 
- Jones, M., Williams, R.C.L., Thomas, S.B., (1971): The effect of seasonal variation and conditions of milk production on the bacteriological quality of refrigerated farm vat milk supplies. J. Soc. Dairy Technol. 24:100-105.

- Keefe, G. P, and Elmoslemany, A. M., (2007): Consumer acceptance of fluid milk after raw milk selection using bulk tank bacteriologic and somatic cell count criteria. Pages 218-219 in Natl. Mastitis Counc Reg. Mtg.Proc., San Antonio, Texas.

- Lauritsen, J. M., and Bruus, M., (2006): EpiData Entry (version 3.1). Data management and basic statistical analysis system. The Epi-Data Association, Odense, Denmark.

- Magnusson,M., Christiansson,A., Svensson, B., Kolstrup, C., (2006): Effect of different premilking manual teat-cleaning methods on bacterial spores in milk. J. Dairy Sci. 89, 3866-3875.

- Murphy, S.C., Boor, K.J., (2000): Trouble-shooting sources and causes of high bacteria counts in raw milk. Dairy Food Environ. Sanit. 20:606-611.

- Pankey, J.W., (1989): Premilking udder hygiene. J. Dairy Sci. 72, 1308-1312.

- Rasmussen, M.D., Galton, D.M., Petersson, L.G., (1991): Effects of premilking teat preparation on spores of anaerobes, bacteria, and iodine residues in milk. J. Dairy Sci. 74, 2472-2478. 
- Reneau, J.K., Seykora, A.J., Heins, B.J., Endres, M.I., Farnsworth, R.J., Bey, R.F., (2005): Association between hygiene scores and somatic cell scores in dairy cattle. J. Am. Vet. Med. Assoc. 227, 12971301.

- Ruegg, P.L., (2004): Managing for Milk Quality. Unpublished. University of Wisconsin. At (http://www.uwex.edu/milkquality /PDF/ managing \%20 for \%20 milk \%20 quality_english.pdf (accessed 6 October 2008).

- Schreiner,D.A., Ruegg, P.L., (2003): Relationship between udder and leg hygiene scores and subclinical mastitis. J. Dairy Sci. 86, 3460-3465.

- Soler, A., Ponsell, C., Paz, M.d., Nunez, M., (1995): The microbiological quality of milk produced in the Balearic Islands. Int. Dairy J. 5, 69-74.

- Van Schaik, G., Lotem, M., Schukken, Y.H., (2002): Trends in somatic cell counts, bacterial counts, and antibiotic residue violations in New York state during 1999-2000. J. Dairy Sci. 85, 782-789.

- Vissers, M.M.M., Driehuis, F., Giffel,M.C.t., Jong, P.d., Lankveld, J.M.G., (2007): Short communication: Quantification of the transmission of microorganisms to milk via dirt attached to the exterior of teats. J. Dairy Sci. 90, 3579-3582.

- Wehr,H.M., Frank, J.F., (2004): Standard Methods for the Examination of Dairy Products. Am. Public Health Assoc. $17^{\text {th }}$ Ed. New York, USA. 


\section{العوامل المؤثرة على زيادة العد البكتيرى الكلى فى مجمع اللبن فى مزارع الألبان

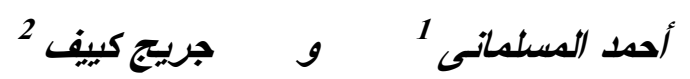

$$
\begin{aligned}
& 1 \text { قسم الصحة و الطب الوقائى - كلية الطب البيطرى - جامعة كفر الثيخ } \\
& \text { 2 قسم الرعاية الصحية - كلية الطب البيطرى - جامعة برنس ادوارد بكندا }
\end{aligned}
$$

أجريت هذه الدر اسة بغرض تحديد العوامل المؤثرة على زيادة العد البكتيرى الكلى فى مجمع

اللبن فى مزارع الألبان. نم تجميع عينات اللبن من مجمع اللبن على مستوى المزرعة من 235 مزرعة ألبان بمقاطعة برنس ادوارد بكندا وذلك كل اسبو عين فى الفترة من أبريل 2005 إلى مارس 2007. نم قياس العد البكتيرى الكلى فى هذه العينات باستخدام نظام أفلام بيتزى الجاهزة. تم جمع البيانات الخاصة بالعوامل المزرعية عن طريق مسح حقلى مكون من أربع نقاط رئيسية وهى:1) بيانات عامة عن المزرعة 2) نظافة و صحة الأبقار 3) طرق تجهيز ألأبقار للحلب 4) تتظيف

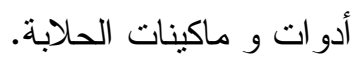

وقد أوضحت نتائج هذه الدراسة أن العد البكتيرى الكلى فى اللبن يزداد بزيادة نسبة تلوث حلمات الضرع قبل تجهيز ألأبقار للحلب و باستخدام التتظيف اليدوى للجمع اللبن و أيضا باستعمال نوع معبن من المنظفات. كما وجد أن طرق تجهيز ألأبقار للحلب مانت من العوامل الهامة وكانت طريقة تغطيس الحلمات ثم تجفيفها قبل الحلابة هى أفضل الطرق للحد من زيادة أن العد البكتيرى الكلى فى اللبن. وقد لوحظ أيضا وجود تأثير معنوى لفصول السنة حيث ان العد البكتيرى كان أقل أثناء الثتاء و أكثر أثناء الصيف.

من هذه الدراسة يتضح أنه يمكن استخدام العد البكتيرى الكلى فى اللبن كدليل على صحة عو امل الرعاية فى مز ارع الألبان. 